In the latter chapters of the book Clark throws caution to the winds. In a remarkably cavalier way he seizes on examples of Christian, Jewish, and gypsy/traveller experience to argue that the persistence of advantage or disadvantage do not disprove his "social law". He thus argues that endogamy amongst the Jewish population, combined with high population growth, explains why their relative high status persists and does not regress to the mean. This interpretation, which sums up Jewish history into a three-page synopsis based on a handful of sources, entirely evades how the relationship between Jewish people and other social groups is organized, and notably the role of anti-Semitism. Even more bizarrely, a photograph of two travellers is used to report that "they do not look like people of Indian descent". It is to be hoped that readers are not offended by this kind of cavalier treatment which appears dismissive of the role of racist forces in history.

Ultimately then, Clark's ambition and confidence proves to be his undoing. Because he puts all his eggs in one basket - of identifying his "social law" - it follows that the book as a whole fails if this law is not convincing. It would be a great shame to disparage the work that has gone into this book. With the remarkable wealth of data at his disposal, Clark could have attempted a more modest but surely more valuable project of elaborating his data sources more contextually, so that they are used to explicate mobility processes in particular nations and times, rather than being yoked to one grand purpose. It would have been fascinating to see much more detail on any of the data bases he has assembled and sensitive reflections on social mobility in any particular context. In fact, we rarely get details of the overall size and descriptive features (most common names at different times, for instance). Perhaps if the big data had been examined with greater attention to detail, a more satisfying book would have been written which could have more clearly identified the power of potential new data sources.

\title{
Mike Savage
}

London School of Economics Houghton Street, London WC2A 2AE, United Kingdom

E-mail: M.A.Savage@1se.ac.uk

African Voices on Slavery and the Slave Trade. Ed. by Alice Bellagamba, Sandra E. Greene, [and] Martin A. Klein. With the ass. of Carolyn Brown. Cambridge University Press, Cambridge [etc.] 2013. xxii, 563 pp. Ill. Maps. £65.00. doi:10.1017/S0020859015000073

In this volume, thirty-five scholars of slavery highlight the voices of the enslaved in Africa. Without question, this is a major contribution to the study of work, workers, and labor relations in the context of African history in the nineteenth and twentieth centuries. While it has been well established that slavery had a profound impact in Africa, not only as a source for the global diaspora of Africans who traveled to the Americas and throughout the Muslim world and the Indian Ocean, it has often been argued that slavery in Africa was somehow different, even more benign, than was the case elsewhere.

These studies elaborate on this complex issue by focusing on sources that have been known almost exclusively to specialists, especially archival documentation and oral sources that enable some understanding of how the enslaved experienced their subjugation 
and understood their dependency. The collection owes its inspiration to Martin Klein, who has been involved in the organization of a series of conferences, first at Bellagio, then the University of Toronto and finally in Buea, Cameroon. Professor Klein has worked closely with his co-editors, Alice Bellagamba and Sandra Greene, and also Carolyn Brown, who collectively have promoted a wide-ranging discourse on the history of slavery in Africa. Because this is a review, it is also necessary to state that I have sometimes been involved in this ongoing exchange, although clearly I am not a contributor to this volume. Nonetheless, I have endorsed this volume because, in my opinion, this collection has "transformed the study of slavery in a way that will require a revolutionary reassessment of what we think about slavery and how we study enslavement and resistance" (back cover).

The structure of the volume is based on a combination of primary documentation and scholarly analysis of the context for the cases of enslavement that are exposed. There are also questions that are intended to guide the reader and provide a means for students to address the key issues of each chapter. Indeed the volume is visionary in its scope and mode of presentation and hence diverges considerably from the standard form of scholarly analysis. This is the reason for my endorsement. The volume is innovative and creative. It deserves the attention of labor historians and historians of slavery, not only in Africa but globally, and the methodological issues that are addressed will be of interest to many other historians as well.

The emphasis on the variety of source material demonstrates the richness of oral and written documentation. The individual cases that draw on selected court records indicate the wealth of materials that actually exist, while the relatively few stories that draw on oral testimonies are but examples from many collections of oral data that have been collected. Biographical texts, some of them very short but many of substantial length, have been amassed, while the records of the "liberated Africans" taken off slave ships by the British Navy in the nineteenth century often reveal considerable detail on the lives of tens of thousands of individuals. Full-length biographical accounts of Africans during the era of slavery are now appearing with some regularity. Taken together, it is now clear that our knowledge of the slave experience, both in Africa and in diaspora, is far more developed than was thought possible as recently as a decade ago. No longer can it be claimed that the voices of the enslaved are silent.

The book is divided into nine sections. In Part I, which includes seven chapters, the focus is on remembering slavery and the slave trade. The documents for this section are primarily oral testimonies, historical tales, and interviews that have been gathered by researchers in different situations, including centralized and non-centralized states, as well as Muslim areas from Kano, Nigeria, to Mingoyo, Tanzania. In Part 2, the focus shifts to the verbal arts and material culture, including songs, prayers, and proverbs. The five chapters in this section range from Yoruba proverbs to lyrics from northwestern Côte d'Ivoire. Part 3 includes three accounts that have been written by African authors, such as Etchu Richard Ayuk's manuscript on the slave trade and social segregation in Ejaghamland, early twentieth-century colonial textbooks, and sources from the emirates of Adamawa. Part 4 turns to the observations of European travelers, and draws on accounts from the Nilotic Sudan, Tunisia, the Algerian Sahara, and the manuscript of Jean Godot on Assini, c.I700. The fifth part introduces colonial administrative records and includes chapters on the Gold Coast, Mauritania, the western Indian Ocean, and the western Sudan. Legal records are the focus of the sixth part, which examines court records in Sierra Leone, Gambia, the Gold Coast, Lagos, and connections with Brazil, and Senegal. Missionary records are the subject of the seventh part and include cases from southern Ghana, French West Africa, Calabar, and Madagascar. Although there are twenty studies in 
the volume that deal with Muslim contexts, there is a separate section of the book specifically on Arabic documentation, including letters from Ghadames in the Sahara, Mauritania, and the Swahili coast. Finally, there is a closing section containing two chapters that deal with the legacy of slavery in contemporary African societies, including two Soninke family biographies and memories of slavery in southern Niger. The editors present each section with a brief introduction.

Despite the considerable praise that I have for this volume, there are some weaknesses that deserve to be discussed. First, several of the maps in the volume could be much better, which is especially important for purposes of teaching. The illustrations, by contrast, are excellent. Second, there are very short bibliographies for each chapter, for reasons that are not really explained and do not seem warranted. There is no collective bibliography for the volume as a whole which thereby reduces its usefulness as a pedagogical tool. It is difficult to understand why this is the case since the book is already very long, and a bibliography would hardly have added to the length but would have increased its usefulness as a resource.

Another factor in assessing the book is the geographical and temporal coverage of the volume. There are parts of Africa that are not covered, which I think is to be expected in a collaborative project of this scope. This is not a weakness, in my opinion, but a challenge. Additional textual material and oral data certainly exist for Angola, South Africa, Mozambique, and many other parts of Africa. It can be expected that these accounts will further expand our understanding of the slave experience. Moreover, accounts of slavery in the contemporary world are also forthcoming and being studied in considerable depth, including sex slavery, child conscription for war, and other forms of slavery that demonstrate that slavery is not a product of the past but extends to the present.

The coverage in this volume includes numerous cases from Muslim areas, which accurately reflects an important division within Africa in the nineteenth and twentieth centuries. The volume also includes cases that are outside the Muslim sphere, as is certainly appropriate. One great contribution of the volume, nonetheless, is the considerable weight it gives to Islamic contexts, which thereby helps to correct an existing bias in the coverage of African history that often does not give sufficient coverage to this component of the past and thereby distorts our understanding of the influence of Islam in Africa today.

Paul Lovejoy

Department of History, York University 4700 Keele Street, Toronto $\mathrm{M}_{3} \mathrm{~J}_{\mathrm{I}} \mathrm{P}_{3}$, Ontario, Canada E-mail: plovejoy@yorku.ca

Bonded Labour and Debt in the Indian Ocean World. Ed. by Gwyn Campbell and Alessandro Stanziani. [Financial History, vol. 22.] Pickering \& Chatto, London [etc.] 2013. xiii, 240 pp. £60.00; \$99.00. doi:10.1017/ So020859015000085

This edited volume on bonded labour in the Indian Ocean rim is one of the latest contributions to a long row of books which appeared in the wake of the 2007 and $201 \mathrm{I}$ bicentenary commemorations of the abolition of the slave trade in the British Empire. 